\title{
KEBEBASAN SISWA DALAM BUDAYA DEMOKRATIS DI SEKOLAH (STUDI MULTI KASUS DI SMA YOGYAKARTA)
}

\author{
Herly Janet Lesilolo, Zamroni, Suyata \\ STAKPN Ambon, Universitas Negeri Yogyakarta, Universitas Negeri Yogyakarta \\ Bunda_noa@yahoo.com,zamroniharjowirono@yahoo.com,
}

\begin{abstract}
Abstrak
Penelitian bertujuan untuk: (1) mendekripsikan alasan sekolah memberi kebebasan kepada siswa; (2) mendeskripsikan alasan bahwa kebebasan siswa dapat dilaksanakan, jika budaya sekolah adalah budaya demokratis; dan (3) mendekripsikan praktik kebebasan siswa dalam budaya demokratis di sekolah. Metode penelitian: kualitatif naturalistik dengan strategi studi kasus, dan menggunakan jenis studi kasus multiple case study. Tempat penelitian, SMA Kolese De Britto Yogyakarta dan SMA Negeri 1 Yogyakarta. Hasil penelitian menunjukkan, (1) Sekolah memberikan kebebasan kepada siswa karena, siswa memiliki keunggulan dan kapasitas. Siswa seharusnya dibiarkan menjadi apa yang mereka pikirkan, rasakan, hadirkan dan lakukan sehingga siswa menjadi mandiri, terinsiprasi dalam mengeksplorasikan kreativitas dan imajinasi. (2) Alasan praktik kebebasan siswa dapat dilakukan dalam budaya demokratis di sekolah karena, budaya demokratis dapat berperan sebagai tenaga penggerak dalam ruang lifelong pembelajaran demokrasi sehingga interaksi, relasi dan perilaku kebebasan siswa tetap teratur secara demokratis, dan (3) Praktik kebebasan siswa yaitu, kebebasan akademik dengan kontrol sosial dan menerapkan kegiatan belajar mandiri. Dalam belajar mandiri, siswa belajar tanpa intervensi guru, siswa secara kritis dan kreatif belajar dengan mengamati, menganalisis, dan sharing. Siswa melakukan interaksi sosial berupa toleransi, saling menghormati dan menerima ide dan kritik, serta kerjasama menciptakan relasi sharing dengan siswa lain membedakan prestasi akademik.
\end{abstract}

Kata kunci: kebebasan, budaya demokratis di sekolah

\section{STUDENTS FREEDOM IN DEMOCRATIC CULTURE IN SCHOOLS (MULTI CASE STUDY IN HIGH SCHOOL YOGYAKARTA )}

\author{
Herly Janet Lesilolo, Zamroni, Suyata \\ STAKPN Ambon, State University of Yogyakarta, State University of Yogyakarta \\ Bunda_noa@yahoo.com, zamroniharjowirono@yahoo.com,
}

\begin{abstract}
This study has a background that the school has not created a space of freedom movement for students to persistent, diligent, disciplined, creative, critical and responsible. Schools are still afraid to admit that students are human beings who are essentially free. Interaction of teachers and students are still stiff and not give priority to freedom as a human right students. Based on the background, the study aims to: (1) decrypt the school grounds to give freedom to the students. (2) describe the reason that the freedom of students can be implemented, if the school culture is a democratic culture, and (3) decrypt the practice of freedom of students in a democratic culture at school. Research methods: qualitative naturalistic case study strategy, and use this type of case studies of multiple case study. Where research, De Britto College High School SMAN 1 Yogyakarta and Yogyakarta. The results showed, (1) School gives freedom to the students because, students have the advantage and capacity. Students should be allowed to be what they think, feel, present and did so students become independent, explored inspired the creativity and imagination. (2) The reason for the practice of freedom of students to do in a democratic culture at school because, democratic culture can act as a driving force within the democratic space so that lifelong learning interactions, relationships and behavior of the freedom of students stay organized democratically, and (3) The practice of freedom of students, namely, academic freedom with social control and implement self-learning activities. In the independent study, students learn without the intervention of teachers, students critically and creatively learn by observing, analyzing, and sharing. Students of social interaction in the form of tolerance, mutual respect and receive ideas and criticism, as well as cooperation create sharing relationships with other students distinguish academic achievement.
\end{abstract}

Keywords: freedom, democratic culture at school 


\section{PENDAHULUAN}

Kebebasan pada umumnya atau seringkali disalahtafsirkan dengan tindakan yang cenderung kebablasan. Kebebasan diartikan sebagai kondisi yang benar-benar bebas, tanpa batas, aturan dan rambu. Padahal selalu ada batas dalam kebebasan dalam suatu situasional. Kebebasan terbatas secara situasional dalam agama, hukum, etika, budaya dan moral.

Rousseau menegaskan, kebebasan dapat membuat manusia merdeka, tidak terbelenggu. Tetapi kebebasan tidak boleh menjadikan manusia anarkis. Orang yang merdeka (bebas) adalah orang yang patuh pada hukum dan peraturan tetapi tidak menjadikan dirinya budak (Rousseau, 1997, p. xvii). Artinya kebebasan yang sebenarnya adalah kebebasan yang memiliki batas.

Dalam pelaksanaan kebebasan, setiap orang harus tunduk semata-mata pada pembatasan yang ditentukan oleh undang-undang. Tujuannya agar menjamin pengakuan dan penghargaan terhadap hak serta kebebasan orang lain, memenuhi syarat-syarat yang adil bagi moralitas, ketertiban serta kesejahteraan umum dalam suatu masyarakat yang demokratis.

Namun, kebebasan juga dapat dianggap ancaman atau dianggap negatif bila akibat kebebasan maka kepentingan individu atau kelompok tidak terpenuhi. Seperti, kebebasan bertoleransi, memilih, atau menggunakan suara. Bentuk kebebasan tersebut dapat dianggap negatif karena yang diutamakan adalah kepentingan bersama bukan kepentingan pribadi atau kelompok. Ada ancaman karena kebebasan berfungsi untuk memenuhi keutamaan dan kesejajaran manusia (Garvey, 2010, p. 152).

Kebebasan pada prinsipnya mengendalikan manusia untuk bertindak dengan memberikan rasa nyaman bagi diri sendiri dan orang lain, serta menyertakan rasa pertanggungjawaban. Kebebasan pun menjadi terbatas karena manusia tidak hidup sendirian melainkan hidup bersama-sama dengan mahluk hidup lainnya.

Selanjutnya kebebasan dalam demokrasi menurut Dewey, bukan hanya sekedar kebebasan dalam tindakan. Namun, kebebasan intelegensi (freedom of intelligence). Komitmen demokrasi untuk kebebasan intelegensi lebih fundamental daripada kebebasan dalam bertindak. Kebebasan intelegensi identik dengan kontrol diri karena dalam kontrol diri intelegensi bekerja sebagai proses pembentukan tujuan sebelum bertindak dan mengatur mengeksekusi tujuan yang dibuat dalam tindakan (Dewey, 1939, p. 67). Tindakan bebas pun menjadi terbatas karena dikontrol diri sendiri.

Di sekolah kebebasan menjadi kebutuhan untuk memberi kontribusi, sehingga kebebasan yang dibutuhkan adalah kebebasan akademik (academic fredoom). Kebebasan akademik mengembangkan prinsip demokrasi dan membantu mengembangkan kecerdasan guru dan siswa (Dewey, 1988, p. 38).

Pengembangan kecerdasan guru dan siswa bertumpu pada kekayaan ilmu yang diperoleh melalui sharing pendapat, kritik, interaksi dan kerja sama. Sikap yang mendukung adalah saling menghormati dan memperhatikan satu sama lain; berpikir kreatif untuk menemukan solusi terhadap problem dan bekerja sama merencanakan dan mengerjakan solusi.

Secara implisit dapat dijelaskan bahwa demokrasi di sekolah, dapat mendorong dan memberikan kesempatan kepada siswa aktif berpartisipasi. Siswa terlibat dalam pengambilan keputusan, siswa menjadi cerdas dalam berpikir dan bertindak secara independen.

Namun, sampai saat ini sekolah masih belum meyakini bahwa, baik kebebasan dalam pengertian umum maupun kebebasan akademik dapat menjadi fondasi untuk meningkatkan prestasi akademik siswa. Akibatnya siswa tidak menemukan jati dirinya sebagai manusia yang kreatif, kaya inisiatif, dan kritis. Siswa harus tetap bergantung pada peraturan, intervensi dan keputusan sepihak dari guru. Siswa tidak berpikir bebas, objektif, kreatif, dan dinamis.

Sekolah sebetulnya tanpa sadar telah melakukan kejahatan kepada demokrasi karena meniadakan kebebasan berpikir dan berekspresi dari manusia. Meniadakan kebebasan berpikir dan berekspresi berarti menghilangkan esensi jati diri dari manusia. Dalam filsafat pendidikan eksistensialisme, esensi jati diri adalah pengembangan kreativitas dan ekspresi pribadi manusia (Gutek, 1977, p. 199).

Bagi Dewey, lingkungan sekolah seharusnya mengkoordinasikan pemahaman 
kebebasan dan posisi kebebasan siswa melalui, membantu siswa melihat kehidupan secara keseluruhan, dan membuka ruang kebebasan yang memungkinkan munculnya ekspresi dan aspirasi siswa.

Interaksi guru dan siswa dapat disederhanakan melalui hubungan yang anti intelektual (Dewey, 1997, p. 22). Hubungan anti intelektual artinya guru memberdayakan kekuatan/kapasitas siswa dalam proses belajar mengajar sehingga membentuk siswa menjadi lebih manusiawi.

Menurut progresivisme agar siswa lebih manusiawi maka proses belajar mengajar bersifat kerjasama melalui penyelidikan masalah atau menganalisis isi pengetahuan. Karena melalui kerjasama siswa belajar menerima orang lain dengan latar belakang yang berbeda seperti, budaya, ras, atau pola pikir (Gutek, 1974, p. 140).

Dalam kerjasama pun muncul kebebasan tetapi dibatasi dengan kontrol sosial. Kontrol sosial adalah kontrol yang sesungguhnya terjadi melalui pengaruh situasi di mana guru dan siswa terlibat berinteraksi. Kontrol sosial terjadi karena ada proses sosial yang membentuk pengalaman edukatif antarindividu dalam masyarakat (Dewey, 1997, p. 51,52).

Agar sekolah dapat leluasa menciptakan kebebasan akademik dengan kontrol sosial, maka budaya demokratis di sekolah berperan penting mengakumulasi dan menularkan dengan singkat pengalaman kebebasan akademik dengan kontrol sosial antar warga sekolah.

Akumulasi dan penularan dilakukan dari waktu ke waktu dan secara terus-menerus melalui penanaman asumsi, pembentukan keyakinan, sikap dan praktik kebebasan akademik dengan kontrol sosial. Melalui kultur demokratis maka, kebebasan akademik dengan kontrol sosial dapat bertumbuh, berkembang dan bergerak secara nyata di sekolah.

Budaya demokratis di sekolah adalah asumsi, keyakinan dan sikap demokratis warga sekolah yang bertahan secara kontinyu dan dari waktu ke waktu, dan tersosialisasi diantara warga sekolah (Heckman, 1993, p. 265). Budaya Demokratis sekolah disinyalir memiliki kekuatan yang dapat diserap warga sekolah. Walaupun tidak nampak tetapi meresap kuat bahkan menjadi komitmen dan pembenaran tindakan demokratis warga sekolah.
Harber melalui penelitiannya memberikan penjelasan bahwa, agar demokrasi dapat dipraktikkan di sekolah maka pengalaman dan keterampilan demokratis harus diajarkan dan diterapkan kepada siswa. Siswa harus dibiasakan berpartisipasi, kurikulum dan metode belajar mengajar memasukan nilai dan praktik demokrasi. Metode pembelajaran perlu bervariasi seperti diskusi, inquiri, proyek, sehingga tercipta relasi untuk berpartisipasi dan bekerja sama (Harber, 1993, p. 6).

Sejalan dengan penelitian di atas, Thronbreg juga menjelaskan bahwa agar sekolah menjadi sekolah demokratis maka siswa dibiasakan mengambil sikap mendengarkan, berunding, mencari argumen, dan mengevaluasi. Dalam relasi dan interaksi terjadi percakapan yang bersifat demokratis yang ditandai dengan siswa mengekspresikan diri melalui komunikasi, memberi alasan untuk mengklaim kebenaran pendapat dan siap memberikan tanggapan atau kritik, serta membiarkan orang lain membuat penilaian (Thronberg, 2010, p. 923).

Budaya demokratis di sekolah membutuhkan relasi dan interaksi demokratis sehingga siswa mengalami pengalaman demokratis secara kontinyu. Siswa melakukan kerja sama, bertoleransi, berlaku tidak membedakan serta saling berbagi pendapat, saran dan kritik.

Kerja sama merupakan nilai penting yang ditanamkan karena kerja sama berkaitan erat dengan kodrat manusia sebagai makhluk sosial yang tidak bisa hidup sendiri dan memerlukan orang lain (Widyaningsih, Zamroni, Zuchdi, 2014, p.188).

Secara jelas dapat dipahami bahwa melalui budaya demokratis maka kebebasan akademik dan kontrol sosial dapat berkembang dengan optimal di sekolah. Sosialisasi kebebasan akademik dan kontrol sosial melalui kultur demokratis menjadikan siswa lebih mandiri dan bertanggung jawab dalam bertindak.

Unsur asumsi dan keyakinan berakar kuat bahwa siswa menjadi cerdas dan mandiri karena ada dorongan dalam diri untuk bertindak bebas dengan kontrol sosial, bukan karena dorongan dari luar; warga sekolah berinteraksi dengan sikap keselarasan, kebersamaan, keadilan, dan tanggung jawab; guru dan siswa saling memberdayakan, siswa bertindak dengan kekuatan sendiri dan percaya diri untuk menyatakan kritik, saran, dan pendapat; 
guru menerima saran dan kritik siswa. Siswa berkembang dengan kapasitas independen dalam bertindak, berpikir dan bertanggung jawab.

SMA Kolese De Britto Yogyakarta dan SMA Negeri 1 Yogyakarta adalah sekolah-sekolah di Yogyakarta yang mengembangkan budaya demokratis di sekolah dengan menerapkan pendidikan bebas.

Pendidikan bebas yang dimaksud bukanlah suatu pendidikan ke arah anarki. Bukan pula suatu sistem pendidikan bebas yang merestui segala penyelewengen dari nilai-nilai yang dicita-citakan. Namun suatu kehidupan bebas yang berlandaskan pengakuan bahwa karunia manusia yang paling asasi dan luhur yaitu kebebasan. Oleh karena itu dalam proses belajar mengajar yang perlu diprioritaskan adalah memperkaya ilmu pengetahuan dan membentuk kepribadian siswa dengan karakter dan moral yang baik.

Lingkungan kedua sekolah membiasakan kondisi belajar yang tidak mengekang, mengatur dan memandu siswa. Kebebasan diintegrasikan dengan tanggung jawab sebagai suatu kesadaran agar siswa bertanggung jawab atas pilihan dan tindakannya. Asumsi dasar warga sekolah dalam berakar kuat pada kebebasan, kemandirian, tanggung jawab dan norma kesopanan.

Warga sekolah berinteraksi demokratis melalui perilaku saling menghormati dan menghargai, saling bekerja sama ditengah perbedaan agama, suku bangsa, etnis, bahasa, dan tidak saling menyingung perasaan antar warga sekolah.

Jika memperhatikan budaya demokratis kedua sekolah ini maka masalah yang perlu diteliti adalah, (1) apa alasan sekolah memberi kebebasan kepada siswa. (2) apa alasannya bahwa kebebasan siswa dapat dilaksanakan melalui budaya demokratis di sekolah, dan (3) bagaimana praktik kebebasan siswa dalam budaya demokratis di sekolah.

Tujuan penelitian yaitu: (1) mendeskripsikan alasan- alasan sekolah memberi kebebasan siswa. (2) mendeskripsikan alasanalasan bahwa kebebasan siswa dapat dilaksanakan melalui budaya demokratis di sekolah, dan (3) mendeskripsikan praktik kebebasan siswa dalam budaya demokratis di sekolah.

Kebebasan akademik siswa didefinisikan sebagai kepercayaan terhadap kapasitas siswa untuk mandiri, kritis, dan bertanggung jawab dalam menentukan, membenarkan atau menyalahkan pilihan dan tindakan. Budaya demokratis di sekolah merujuk pada, asumsi, keyakinan, nilai, dan praktik demokratis warga sekolah sekolah. Peran budaya demokratis yaitu, menggerakkan interaksi bebas dengan kontrol sosial. Lingkungan sekolah demokratis berbentuk lingkungan sosial yang memberi kontribusi pengalaman melalui relasi, interaksi dan komunikasi secara demokratis.

\section{METODE PENELITIAN}

Jenis penelitian yang digunakan adalah kualitatif naturalistik dengan strategi studi kasus, dan menggunakan jenis multiplecase study. Penelitian dilakukan di SMA Kolese De Britto Yogyakarta dan SMA Negeri 1 Yogyakarta. Waktu penelitian, Januari sampai dengan Juli 2014. Alasan pemilihan kedua sekolah sebagai tempat penelitian yaitu, kedua sekolah memiliki budaya demokratis. Budaya demokratis teramati pada perilaku warga sekolah yang saling menghormati, saling menghargai perbedaan. Proses belajar mengajar memiliki ciri pendekatan berpusat pada siswa, guru merangsang siswa berpikir kritis dan kreatif; guru menggunakan metode mengajar yang bervariasi dan kondisi PBM fleksibel, siswa mandiri menemukan solusi dalam pemecahan masalah, saling bertanya, memberi kritik dan saran, serta mengontrol diri saat melakukan kerjasama dengan guru atau antar siswa.

Pengambilan subjek didasarkan pada asumsi bahwa subjek sebagai pemeran yang memiliki asumsi, keyakinan, nilai dan praktik kebebasanakademik dengan kontrol sosial yang cukup menonjol di sekolah. Subyek guru yang dipilih terwakili sebagai salah satu guru yang akrab secara demokratis dengan siswa. Di mana siswa diberi kepercayaan untuk menentukan. membenarkan atau menyalahkan tindakan yang dilakukan dan melakukan komunikasi yang terbuka dengan siswa. Siswa yang dipilih adalah siswa yang memiliki ciri aktif dan kurang aktif, juga siswa yang berprestasi akademik tinggi, sedang, rendah.

Peneliti menghubungi pihak-pihak yang menjadi sumber data untuk mendiskusikan dan menetapkan jadwal pertemuan dan cara-cara pemerolehan data yang diperlukan. Kemudian menyusun pedoman observasi partisipasi (participant observation), pedoman 
wawancara mendalam (Indepth Interview), dan dokumentasi, prosedur kedua, Peneliti merumuskan daftar pertanyaan terbuka untuk meminta jawaban/pendapat dari subjek yang diteliti. Sekuensi pertanyaan terbuka tidaklah sama pada tiap partisipan bergantung pada proses wawancara dan jawaban tiap individu, peneliti pada tahap ketiga melakukan kontrak waktu dengan partisipan, sehingga mereka dapat merencanakan kegiatannya pada hari itu tanpa terganggu oleh wawancara, dan pada tahap keempat peneliti menentukan dokumentasi berupa, sumber tertulis atau dari dokumen yang ada pada responden atau tempat.

Observasi partisipasi dilakukan selama penelitian dimulai dari observasi menyeluruh, subyek teramati yaitu guru dan siswa selama berlangsungnya proses belajar mengajar). Peneliti hanya sedikit ambil bagian dalam kegiatan objek yang diamati. Dalam hal ini peneliti tidak sepenuhnya terlibat, hanya sekilas saja (surfice participation) jika kondisi ini sesuai keinginan subjek. Kehadiran peneliti dalam observasi partisipatif kemungkinan dapat diketahui atau tidak diketahui terhadap relasi guru dengan siswa yang berlangsung dalam PBM, tindakan-tindakan siswa secara mandiri dalam upaya menguasai kompetensi, menafaatkan lingkungan dan media belajar yang tersedia di sekolah.

Setelah peneliti menerima data melalui observasi partisipatif, wawancara mendalam, maka peneliti melakukan pengkodean secara terbuka. Dari hasil pengkodean tersebut peneliti kemudian melakukan pengkodean terporos dengan cara peneliti mengidentifikasi fenomena sentral guru dan siswa dalam proses belajar mengajar dalam konteks budaya demokratis, menjajaki kondisi proses belajar mengajar yang berciri kebebasan, menspesifikasi relasi, interaksi dan sikap bebas guru dan siswa, mengidentifikasi bentuk kebebasan yang dapat dilakukan dalam budaya demokratis di sekolah, dan menggambarkan konsekuensi dari tindakan kebebasan dari budaya demokratis di sekolah. Kemudian pada tahapa pengumpulan data peneliti melakukan pengkodean terpilih, dimana peneliti melihat secara selektif kasus-kasus yang mengilustrasikan tema-tema hasil pengkodean sebelumnya dan membuat perbandingan. Langkah yang dilakukan, mereproduksi kembali alur cerita, mengidentifikasi data dengan menulis kalimat penedek yang merupakan inti cerita, menyim- pulkan dan memberi kode terhadap satu atau dua kalimat, sebagai kategori inti yang dapat mencakup semua fenomena/data, menyimpulkan dan memberi kode terhadap satu atau dua kalimat sebagai kategori inti yang dapat mencakup semua fenomena/data.

\section{HASIL PENELITIAN DAN PEMBAHASAN}

Budaya demokratis di SMA Kolese De Britto Yogyakarta dan SMA Negeri 1 Yogyakarta berperan menggerakkan kebiasaan interaksi dan relasi bebas berupa, siswa mengambil keputusan dan bertindak sesuai hati nuraninya yang benar, mengormati guru dengan memberi salam dan mencium tangan guru, tidak terbelenggu oleh gengsi, materi, atau kecenderungan untuk ikut-ikutan bertindak bebas.

Guru SMA Kolese De Britto menjelaskan bahwa, rambut pendek, seragam serba lengkap, dan upacara tidak menjamin seorang siswa akan terbentuk karakter dan kepribadiannya. Peraturan dan paksaan tidak lagi digunakan dalam jalur pendidikan. Siswa bebas mengeksplorasi kreatifitas mereka dengan tetap menyadari hak serta kewajiban siswa (Hasil wawancara dengan guru PS; 273-2014).

Guru SMA Negeri 1 Yogyakarta berpendapat siswa dalam kebebasan, dibiasaOkan memilih untuk bertindak menghargai dan menghormati sesama manusia. Semboyan 6S, salam, sapa, senyum, sopan, santun, dan sederhana merupakan wujud dari keyakinan warga sekolah untuk saling menghormati dan menghargai.

Temuan penelitian di atas memperlihatkan bahwa kebebasan dalam kultur demokratis kedua sekolah dilatarbelakangi dengan asumsi dan keyakinan bahwa siswa adalah mahkluk yang bebas, dapat berdiri sendiri dan mampu bertindak tanpa paksaan pihak lain. Siswa mampu membuat pilihan dengan melakukan sesuatu yang bermanfaat bagi orang lain. Kontrol sosial terwujud melalui sikap saling menghormati dan menghargai antar warga sekolah.

Guru berpendapat bahwa kebebasan manusia pada satu sisi merupakan suatu kemampuan untuk memberikan arti dan arah kepada hidup dan karya, kemampuan untuk menerima atau menolak terus menerus ditawarkan kepada manusia. Dalam menentukan 
pilihan manusia ditentukan oleh faktor-faktor diluar kemampuannya sendiri, seperti halnya pembauran kondisi sosialnya. Dan pada sisi lain manusia secara otonom ikut menentukan tindakannya. Oleh karena itu SMA Kolese De Britto Yogyakarta mengembangkan kultur demokratis dengan ciri kebebasan mandiri dan bertanggung jawab atas pilihan dan tindakan yang dilakukan. (Hasil wawancara dengan guru LH; 3-5-2014).

Pendapat searah dikemukakan oleh guru di SMA Negeri 1 Yogyakarta bahwa manusia diberikan kebebasan menentukan pilihan yang bertanggung jawab, karena ada konsensus moral dalam bentuk aturan bersama yang harus ditaati dan mengikat. SMA Negeri 1 Yogyakarta menerapkan kebebasan dengan norma kesopanan. Bertindak bebas tetapi dibatasi norma kesopanan. Siswa secara rasional dapat melakukan pengontrol tindakan yang tidak berakibat buruk bagi orang lain (Hasil wawancara dengan guru DW; 15-3-2014)

Dalam proses belajar mengajar di SMA Kolese De Britto Yogyakarta dan SMA Negeri 1 Yogyakarta, kedua sekolah melaksanakan kebiasaan siswa belajar tanpa pengawasan guru.

Guru di kedua sekolah meyakini bahwa kebebasan adalah proses perkembangan dan karenanya harus ada ruang dan kesempatan bagi kebebasan berkembang. Kebebasan berkembang apabila siswa diberi kesempatan belajar mengembangkan kesanggupan siswa tanpa intervensi guru.

Guru membiasakan siswa secara bebas menjatuhkan sendiri pilihan pada pola pikir, pendapat, ide, ekspresi, kritik dan solusi siswa untuk menyelesaikan masalah atau tugas tanpa kehadiran guru memantau aktivitas belajar siswa.

Dalam proses pembelajaran bidang studi biologi di kelas XI dipelajari tentang struktur dan fungsi sel sebagai unit terkecil kehidupan. Pelaksanaan proses belajar mengajar guru menjelaskan materi secara singkat berupa apersepsi, menjelaskan tujuan yang dicapai dan memberikan waktu selama lima belas (15) menit untuk siswa menonton film. Film berjudul How to Build The Human Body. Guru meninggalkan kelas dan membiarkan siswa belajar melalui tayangan film.

Ketika guru meninggalkan kelas ma$\mathrm{ka}$, siswa mengatur diri sendiri mencari teman dua sampai tiga orang untuk melihat tayangan film. Siswa saling memberi berpendapat dan saling mengkritik.

Di SMA Negeri 1 Yogyakarta dengan bidang studi yang sama siswa diberi kesempatan belajar menyelesaikan masalah melalui studi kasus di alam. Tanpa intervensi guru siswa membuka lap top menggunakan fasilitas internet mencari informasi tentang masalah yang harus dipecahkan, saling tolong menolong meminjam lap top bagi siswa yang membutuhkan, siswa ke perpustakaan mencari informasi melalui buku, majalah dan jurnal, ketika menemui kesulitan siswa mencari siswa yang lain untuk saling memberi saran atau ide dan masing-masing siswa menarik kesimpulannya sendiri. Siswa terlihat mengendalikan diri untuk meminjam fasilitas temannya, tidak bertindak bebas atau memaksa, ketika hendak menggunakan fasilitas di perpustakaan tetapi fasilitasnya masih dipakai siswa lain, siswa bersikap sabar dengan membaca buku atau jurnal lainnya.

Menurut siswa, dalam belajar mandiri siswa lebih bebas bekerja sama dengan siapa saja, mencari jawaban atau solusi dengan motivasi jawabannya harus benar; berusaha mencari informasi yang benar dan tepat, tidak bergantung kepada orang lain tetapi menerima pendapat orang lain untuk mempertimbangkan kebenaran informasi yang sudah diperoleh. Tidak bergantung juga kepada pendapat guru, tetapi dengan menemukan informasi yang tepat siswa dapat memberi pertimbangan bahwa jawaban atau solusi yang dikerjakan adalah benar (Hasil wawancara dengan siswa PH; 13-3-2014).

Berdasarkan observasi, juga pendapat siswa dan guru maka dapat ditegaskan bahwa kebebasan akademik di kedua sekolah berorientasi pada kebebasan berpikir untuk mencari dan menemukan informasi atau pengetahuan, dan mandiri menentukan sumber atau media yang membantu menemukan jawaban atau solusi.

Siswa dalam suasana kebebasan menjadi manusia yang bebas namun sabar. Siswa mampu mengambil keputusan dan bertindak sesuai dengan hati nuraninya yang benar, bertindak bebas tetapi membatasi diri dengan kontrol sosial yang tepat.

Kebebasan siswa dalam belajar mandiri mendorong siswa berpikir dan berpendapat bersumber dari diri siswa sendiri, bukan dari luar. Setiap siswa mampu dan berani 
memberikan argumen untuk posisi yang berbeda atau kritik, membuat refleksi dan pertimbangan dari pengetahuan yang yang diperoleh untuk menyelesaikan masalah.

Proses belajar mandiri membiasakan siswa aktif mendiagnosa setiap informasi/ pengetahuan dengan masalah yang akan dipecahkan; ssiwa menentukan upaya belajar sendiri agar memperoleh data atau informasi yang tepat dan benar, mengidentifikasi sumbersumber belajar yang membantu menemukan informasi, dan mengevaluasi hasil kerja sendiri melalui sharing informasi dengan siswa lain untuk mengambil kesimpulan yang tepat.

Secara demokratis belajar mandiri membuka ruang interaksi dan kerja sama di antara siswa sehingga memberi kemungkinkan adanya peluang menemukan gagasan. Antar siswa terjadi upaya saling melengkapi pendapat dan gagasan sehingga alur pemikiran siswa dapat berkembang.

Kultur demokratis di SMA Kolese De Britto Yogyakarta dan di SMA negeri 1 Yogyakarta pada prinsipnya memberi kebebasan yang mandiri, bertanggung jawab dengan norma kesopanan. Siswa mandiri, bebas menentukan tindakan dan pilihan tetapi harus bertanggung jawab terhadap pilihan dan tindakan. Siswa bebas bekerjasama tetapi norma kesopanan membatasi atau menjadi kontrol sosia dalam interaksi dan kerjasama.

Kultur demokratis mendorong siswa dapat mengalami dan mempelajari secara terus-menerus esensi realitas kebebasan akademik dengan kontrol sosial. Akibatnya siswa pun menyadari bahwa sikap bebas dapat membantu siswa menyelesaikan masalah atau tugas dalam kegiatan belajar secara optimal. Siswa juga menyadari dapat bertindak bebas tetapi harus mengontrol diri agar tindakan yang dilakukan demi kebaikan dan kenyamanan bersama.

Kebebasan siswa pun menjadi melekat dengan kebebasan yang menyertakan tanggung jawab. Secara manusiawi, siswa harus dapat memberikan pertanggungjawaban pada dirinya sendiri dan pada manusia lain (yang sama dasar kemanusiaannya) tentang apa yang dilakukannya.

Kebebasan akademik melalui proses belajar mandiri membiasakan siswa tidak perlu takut berinisiatif untuk mengemukakan pendapat, mengkritik atau memberi argumen dan memberi gagasan. Interkasi guru dan siswa melalui kerjasama, sharing dan menerima saling menerima pendapat, telah dipelajari siswa sebagai interaksi yang tidak mengancam dan tidak merugikan siswa.

Rangkaian interaksi belajar mandiri di atas membawa perasaan percaya diri siswa untuk mengembangkan kreativitas dan ekspresi siswa. Artinya dalam belajar mandiri siswa menentukan sendiri esensi jati dirinya dan secara independen siswa berpartisipasi memberi argumen untuk merefleksikan pengalaman temuannya sendiri. Secara rutin isyarat kebebasan akademik dengan kontrol sosial melalui belajar mandiri memberi keadaan jiwa atau pikiran siswa dengan kesan yang baik.

\section{SIMPULAN DAN SARAN}

\section{Simpulan}

SMA Kolese De Britto Yogyakarta dan SMA negeri 1 Yogyakarta mempraktikkan kebebasan akademik dengan kontrol sosial karena meyakini bahwa, siswa memiliki kapasitas yang kritis dan etis untuk bertanggung jawab terhadap pilihan dan tindakan yang dilakukan.

Kultur demokratis di sekolah dapat menggerakkan dan merespon secara tepat kebebasan akademik dengan kontrol sosial melalui asumsi, keyakinan, sikap dan praktik demokratis warga sekolah. Kultur demokratis memiliki kapasitas untuk menilai dan melekatkan interaksi, komunikasi, dan perilaku kebebasan warga sekolah dengan kontrol sosial yang tepat.

Praktik kebebasan akademik dengan kontrol sosial dalam kultur demokratis di sekolah adalah belajar mandiri. Belajar mandiri merujuk pada belajar tanpa ada intevensi dan pengawasan guru. Siswa menyusun dan menentukan gagasan, metode dan sumber belajar sesuai kebutuhan siswa sendiri.

\section{Saran}

Budaya sekolah sebaiknya mengembangkan kultur demokratis agar pemograman pola pikir dan totalitas perilaku warga sekolah dapat menularkan secara singkat kebebasan akademik dengan kontrol sosial.

Proses belajar mengajar sebaiknya mempolakan dan mempraktik belajar mandiri. Dalam belajar mandiri siswa aktif, mencari 
dan menentukan cara belajar yang tepat bagi siswa, mengembangkan pengetahuan dan keterampilan yang dipelajarinya, mengembangkan rasa percaya diri dan menciptakan interaksi sosial yang positif.

\section{DAFTAR PUSTAKA}

Dewantara, K.H., (1977). Pendidikan. Yogyakarta: Majelis Luhur Persatuan Taman Siswa.

Dewey, J. (1997). Experience and education. USA: Published by agreement with Southern Illinois University Press.

(1988). The soical signifigance of freedom academic. Education Digest. 1, 37-38.

(1938). Experience and education. Toronto: Collier-MacMillan Canada Ltd.

(1939). Freedom and culture New York: Putnam.

Garvey, James, 2010. 20 Karya Filsafat Terbesar. Diterjemahkan oleh CB. Mulyatno Pr. Yogyakarta: Kanisius.
Gutek, L.L. (1974). Philosophical alternatives in education. Columbus, Ohio: Charles E. Merril Publishing Company

Harber, C. (1993). Democratic management and school effectiveness in Africa: Learning from Tanzania. Compare, $23,1-8$.

Heckman, P.E., (1993). School restructuring in practice reckoning with the culture school. International Journal of Educations Reform, 3, 263-271.

Thornberg, R. (2010). School democratic meetings: Pupil control discourse in disguise. Teaching and Teacher Education, 26, 924-932.

Widyaningsih, T. S., Zamroni, Zuchdi, D., (2014). Internalisasi dan aktualisasi nilai-nilai karakter pada siswa SMP dalam perspektif fenomenologis (Studi kasus di SMP 2 Bantul). Jurnal Pengembangan Pendidikan. Fondasi dan Aplikasi. 2, 181-195.

Rousseau, J.J (1997). The social contract and other later political writings. Cambridge: Cambridge University Press. 